\title{
THE RE-DESIGN PROCESS OF AN INSTRUMENT TO EVALUATE USABILITY IN ONLINE COURSES
}

\author{
Zoroayka V. Sandoval, The University of Texas Rio Grande Valley, vicky.sandoval@gmail.com
}

\begin{abstract}
Usability in e-learning has been measured in order to improve students' satisfaction (Nasreen \& Alawi, 2011; Davids, Chikte, \& Halperin, 2014). In order to measure courses' usability in higher education online courses, the ELearning Usability Evaluation Questionnaire developed by Zaharias (2009) is the closest instrument available. However, this instrument was originally designed for corporate settings and an adaptation was required to use it in higher education online courses. The adaptation process, including re-wording of the questions and experts' input to obtain the adapted version of the questionnaire is described in this article. Results of the adaptation process are described, as well as validity and reliability of the redesigned instrument. Some recommendations for the use of the new version of the questionnaire are discussed.
\end{abstract}

Keywords: Usability, Usability Assessment Instrument, Online Courses, Higher Education, E-Learning.

\section{INTRODUCTION}

Usability has played an important role in web design. As technology and web design have evolved, researchers have created and compiled rules and heuristics to enhance web design usability's attributes, such as navigation, accessibility, efficiency, and design. According to Mazumder and Das (2014), these rules "give the direction to the designer to produce usable systems (p. 80)." Usability rules have been also applied in e-learning to evaluate online courses' usability.

Researchers have been evaluating usability in e-learning using different evaluation methods, such as heuristics, checklists, and think aloud protocols (Khan, Israr, \& Hassan, 2010; Davids, Chikte, \& Halperin, 2014). In most research studies, the usability evaluation results have helped in the improvement of the e-learning settings. However, most of the studies found are focused only on the web design of the online e-learning settings. Some researchers have considered including pedagogical aspects when conducting usability evaluations in e-learning (Granić \& Ćukušić, 2011; Dringus \& Cohen, 2005; Nyang'or, De Villiers, \& Ssemugabi, 2013; Zaharias \& Koutsabasis, 2012). In order to evaluate usability in online higher education courses, a few instruments were found which include web design and pedagogical elements (Zaharias, 2009; $\mathrm{Hu}, 2008$ ).

The E-learning Usability Evaluation Questionnaire developed by Zaharias (2009) was the closest instrument to evaluate usability in higher education online courses. However, it was designed to measure e-learning usability in corporate settings. Therefore, an adaptation of this instrument was required in order to have an option of a nonproprietary instrument available for measuring usability in higher education courses.

In this study, the E-learning Usability Evaluation Questionnaire (Zaharias, 2009) was adapted for higher education educational environments. Faculty teaching online and online course designers could benefit from having access to an e-learning usability instrument to aid in the design and evaluation of fully online university courses based on users' perceptions. The instrument could assist them in examining to what degree they have incorporated usability principles to the designed courses. The results of the usability evaluation will help stakeholders in the improvement of the design of the courses and as a consequence, the overall experience of the users. 


\section{LITERATURE REVIEW}

Usability in e-learning has been measured and studied by researchers (Nyang'or, Ssemugabi, \& De Villiers, 2013; Feldstein \& Neal, 2006; Aziz, Isa, \& Nordin, 2010; Davids, Chikte, \& Halperin, 2014). Research includes studies on usability of e-learning settings, such as e-learning platforms, web 2.0 applications, and offline e-learning tutorials (Stergioulas, et. al., 2014; Orehovacki \& Hrustek, 2013; Nyang'or, De Villiers, \& Ssemugabi, 2013), and also usability of online courses (Aziz, Isa, \& Nordin, 2010; Ballard, 2010; Fisher \& Wright, 2010; Dringus \& Cohen, 2005). Usability is defined by the International Organization for Standardization (ISO) as "the extent to which a product can be used by specified users to achieve specified goals with effectiveness, efficiency and satisfaction in a specified context of use" (as cited in Jokela, Iivari, Matero, \& Karukka, 2003, p. 53). Considering software as the context of use for e-learning, Bevan, Kirakowski, and Maissel (1991) argued that usability in software development can be measured from different views: the product-oriented view, the user-oriented view, and the user-performance view. Most usability guidelines suggested in the literature are user-performance oriented, which include evaluating the ease-of-use and acceptability of the software or webpage (Bevan, Kirakowsky, \& Maissel, 1991). These guidelines "give the direction to the designer to produce usable systems" (Mazumder \& Das, 2014, p. 80).

In order to produce usable systems, three usability attributes can be measured based on the abovementioned usability definition: (1) effectiveness, (2) efficiency, and (3) satisfaction. These usability attributes are found in some wellknown usability models, such as Nielsen's usability heuristics (Nielsen, 1995a) and Shneiderman's Eight Golden Rules (Shneiderman \& Plaisant, 2010). These models offer criteria to help produce usable interfaces (Mazumder \& Das, 2014), including guidelines that are based on the usability attributes along with new attributes, such as learnability and flexibility, which are related to website usability (Abran, Khelifi, Suryn, \& Seffah, 2003).

According to Shackel (2009), there are three principal usability evaluation procedures: (1) expert review, (2) simulation trials, and (3) user performance tests. Based on this, usability guidelines can be used in e-learning in different ways, for example, as a checklist for designers that includes all the basic elements to create a usable course, or as a checklist where experts can evaluate a course's usability. Also, these guidelines can be used to measure a course's usability based on the user's performance and perception about the course.

Some well-known guidelines, such as Nielsen's heuristic evaluation (Nielsen, 1995b), have been used in research to measure usability in e-learning (Aziz, Isa, \& Nordin, 2010; Ballard, 2010; David \& Glore, 2010; Davids, Chikte \& Halperin, 2014), while some other researchers have created their own set of guidelines to measure usability in their specific settings (Nyang'or, Ssemugabi, \& De Villiers, 2013; Dringus \& Cohen, 2005; Zaharias, 2009). Most of the e-learning usability studies found are focused on the web-design aspects of the courses.

According to research (Heidig, Müller, \& Reichelt, 2015; Malamed, 2015; Plass, Heidig, Hayward, Homer, \& Um, 2013) e-learning course design plays an important role in preventing online learner frustration, thereby impacting student satisfaction. However, since the purpose of e-learning is not only to provide an interface for an online learning environment, but also to support the acquisition of knowledge through it, the traditional usability instruments are not sufficient (Nyang'or, Ssemugabi, \& De Villiers, 2013). Zaharias and Koutsabasis (2012) state, "usability of e-learning systems and applications is directed toward optimizing the learner experience along the two main axes: technical (or web) usability and pedagogical usability (p. 47)." Based on this, a usability measurement of a fully online course should consider not only the web interface design, but also pedagogical components, such as communication and learning tools, content, and tasks included in the learning environment (Silius, Tervakari, \& Pohjolainen, 2003). As a result, researchers have considered additional pedagogical components when conducting usability evaluations of e-learning environments (Hu, 2008; Dringus \& Cohen, 2005; Zaharias, 2009; Nokelainen, 2006) and new heuristic checklists have been developed. While there is limited research where the overall usability, including pedagogical components, is tested in online courses (Zaharias, 2009; Hu, 2008), there are several instruments available, but many, such as Quality Matters, are proprietary. This makes them very costly, both in the financial cost to access it, and the training time and certifications required for users. 


\section{Issues in Information Systems \\ Volume 17, Issue III, pp. 77-88, 2016}

\section{The E-learning Usability Evaluation Questionnaire}

Of all of the usability instruments reviewed, the E-learning Usability Evaluation Questionnaire created by Zaharias (2009) was the most appropriate to measure usability in online higher education courses because it was the first free and readily available instrument found to measure usability specifically for e-learning environments. Zaharias (2009) proposed a questionnaire-based usability evaluation method for e-learning, considering cognitive and affective factors which may have an effect in e-learning usability. The eight proposed criteria in Zaharias' (2009) $E$ learning Usability Evaluation Questionnaire are: (1) content, (2) learning and support, (3) visual design, (4) navigation, (5) accessibility, (6) interactivity, (7) self-assessment and learnability, and (8) motivation to learn. This can be considered the closest instrument to measure usability in e-learning because many factors related to online university courses are included. However, this questionnaire is not adequate for educational settings, since it was created for corporate training settings.

Given the lack of an affordable, easily accessible instrument to measure usability in online university courses, for this study, the E-learning Usability Evaluation Questionnaire (Zaharias, 2009) was adapted to educational settings. This will help fill the need for an instrument that allows university faculty and stakeholders a valid and reliable way to analyze and improve usability in fully online higher education courses. During the adaptation process, which is presented in the Methodology section below, two additional criteria were added to the redesigned version of the questionnaire. These criteria are Assessment and Instructor Presence.

\section{Assessment in Online Courses}

As argued by Swan, Shen, and Hiltz (2006), instructors usually assess the skills and behaviors that are considered most important and valuable to a course. This way, the instructors are able to give feedback and guide the students through their learning process. Course assessment is considered one of the most important parts in an online course because "it has a strong impact on learning and is an indicator of the quality of learning occurring in a class" (Arend, 2007, p. 3).

Researchers (Gaytan \& McEwen, 2007; Arend, 2007; Swan, Shen \& Hiltz, 2006; Rochester Institute of Technology, n.d) have reported assessment methods that can be used in online courses. These methods include but not are limited to: (1) threaded discussions, (2) final/midterm examinations, (3) quizzes, (4) individual projects, (5) collaborative projects, (6) peer evaluations, (7) portfolios, (8) papers/essays, among others. By using a variety of assessment methods, online students are able to demonstrate in different ways their performance development. Gaytan and McEwen (2007) have identified flexibility, immediate feedback, and reflective thinking as the advantages of online assessments.

Because online assessment methods can be diverse, researchers recommend the use of grading rubrics to provide detailed expectations about students' performance (Swan, Shen \& Hiltz, 2006; Arend, 2007; Rochester Institute of Technology, n. d.; Gaytan \& McEwen, 2007; Poe \& Stassen, n. d.). With clear and available rubrics and instructions, students can use their time effectively completing graded assignments without waiting for the instructor to respond a question. Therefore, it is important to consider the usability of assessment methods in an online course, in order to offer clear and available instructions for all the required activities.

\section{Instructor Presence in Online Courses}

Teaching presence is the "design, facilitation, and direction of cognitive and social processes for the purpose of realizing personally meaningful and educationally worthwhile learning outcomes (as cited in Jones, 2011, p. 78)." Based on this, instructor's interaction in online courses plays an important role in facilitating and guiding students' learning acquisition in a course. According to Baker (2010), instructor's presence is a significant predictor of student affective learning, cognition, and motivation in the online environment. In order to create a learning community and increase interaction, the instructor uses a variety of technological tools, such as discussion boards, emails, chats, and messages, to reduce physical distance and increase communication among course participants and instructor. 
One of the instructor's roles is to be the course facilitator. Therefore, it is important to be actively present throughout the course duration. The instructor can create an accepting climate for learning, keep students on track, and give feedback to reinforce or confirm students' understanding (Shea, Li, \& Pickett, 2006; Shea, Li, Swan, \& Pickett, 2005). As Tu and McIsaac (2002) argue, response time is a critical issue to the online interaction between instructor and students, particularly in courses with asynchronous communication. Students need on-time responses to the questions and issues they might have when taking an online course, in order to complete assignments and continue with the course flow. As Jones (2011) argues, "if the online course design includes multiple methods giving students notice of key course items and encouraging faculty-student interaction (p. 99)," then teaching presence can be achieved.

Given that teacher presence is a significant component in an online course, it is important to consider the usability of instructor presence. Students taking online courses need to have continuous communication with the instructor to overcome issues and answer questions that could interrupt their learning process.

\section{METHODOLOGY}

The E-learning Usability Evaluation Questionnaire developed by Zaharias (2009), was originally designed to measure e-learning usability in corporate trainings. The purpose of this study was to redesign the instrument so it can be used to measure usability in fully online higher education courses. In order to conduct this study, the original questionnaire by Zaharias (2009), was redesigned by adapting the wording and focus of some questions to evaluate usability in online higher education courses, as well as adding two sets of new questions in the areas of instructor presence and assessment. The redesign process of the original instrument is described below.

\section{The Redesign Process}

Since the original usability instrument by Zaharias (2009) was designed for corporate settings, numerous questions, e-learning technologies, and learning strategies did not apply to online courses in higher education. In addition, because it was developed over 5 years ago, many e-learning technologies have changed. Therefore, the original questionnaire by Zaharias (2009) was adapted in order to be used with fully online university courses. To validate the rewording of the original questions in the survey, experts were invited to conduct a pilot study. The adaptation process of the original questionnaire was conducted in three phases. The three adaptation phases are explained below.

\section{Phase 1: Initial Questionnaire Adaptation}

In the first phase of the questionnaire adaptation process, Zaharias' (2009) original questionnaire was reviewed and adapted by the researcher to rephrase the questions, keeping a similar meaning for each, but integrating criteria, technologies, and pedagogies used in e-learning specifically in online university courses. An excerpt of the original and the adapted questions in this Phase are shown in Table 1. From Zaharias' (2009) original questionnaire, ten items related to the criteria motivation to learn were removed. Zaharias (2009) researched the relationship between motivation to learn and usability in e-learning. The questions on motivation to learn were beyond the scope of the present study because its purpose was to redesign the instrument to measure usability in online higher education courses. The final questionnaire from this phase had a total of 29 questions, and 14 questions were kept as the original questions.

Table 1. Excerpts of Phase 1 Adaptation Process

\begin{tabular}{|l|l|}
\hline \multicolumn{1}{|c|}{ Original Question } & \multicolumn{1}{c|}{ Adapted Question } \\
\hline $\begin{array}{l}\text { Abstract concepts (principles, formulas, rules, etc.) } \\
\text { are illustrated with concrete, specific examples. }\end{array}$ & $\begin{array}{l}\text { Difficult concepts are illustrated or explained } \\
\text { using examples. }\end{array}$ \\
\hline $\begin{array}{l}\text { Learners can choose (easily) what part of the course } \\
\text { to access, the order and pace of studying. }\end{array}$ & $\begin{array}{l}\text { Learners can follow in a logical order the part of } \\
\text { the course that is intended for a specific week or } \\
\text { module. }\end{array}$ \\
\hline The course is easy to install, uninstall, and launch. & The course is easy to find and access. \\
\hline
\end{tabular}


Phase 2: Experts' Review and Adaptation

In the second phase, the adapted version of the E-Learning Usability Evaluation Questionnaire that resulted from Phase 1 was reviewed by a team of two different experts in the field. These experts were selected, using purposive sampling, because both are academic experts in e-learning, having more than 16 years of experience each, teaching and designing fully online synchronous and asynchronous courses. At the time of their participation in this study, both experts were teaching online courses at a higher education institution. In this phase, the experts provided feedback on the adapted version from Phase 1. Their suggestions and comments were analyzed to revise the questionnaire. Some of the revised questions are shown in Table 2.

Table 2. Excerpts of Revised Questions

\begin{tabular}{|l|l|}
\hline \multicolumn{1}{|c|}{ Reviewed Question } & \multicolumn{1}{c|}{ Revised Question } \\
\hline $\begin{array}{l}\text { Media are used appropriately so as to assist in } \\
\text { highlighting and learning critical concepts rather } \\
\text { than merely entertaining or possibly distracting } \\
\text { learners. }\end{array}$ & $\begin{array}{l}\text { Media highlight concepts rather than distract or } \\
\text { merely entertain learners. }\end{array}$ \\
\hline $\begin{array}{l}\text { The course provides meaningful } \\
\text { interactions (for example embedded } \\
\text { quizzes, tests, etc.) when there are long } \\
\text { sections of text. }\end{array}$ & $\begin{array}{l}\text { The course provides meaningful interactions (i.e. } \\
\text { self-check embedded quizzes, reflection activities) } \\
\text { when there are long sections of text. }\end{array}$ \\
\hline $\begin{array}{l}\text { The course provides support for learner activities } \\
\text { to allow working within existing competence } \\
\text { while encountering meaningful chunks of } \\
\text { knowledge. }\end{array}$ & $\begin{array}{l}\text { The course provides support to allow students to } \\
\text { build on prior knowledge and skills to complete } \\
\text { activities. }\end{array}$ \\
\hline
\end{tabular}

Experts' comments were analyzed and incorporated into the questionnaire. As a result of this phase, a total of 7 questions were added. One question was added to the existing section on navigation; 3 for a new section regarding the usability of course assessments; and 3 for another new section on instructor presence, resulting in a newly adapted version of the questionnaire with 36 questions. At this point, no additional questions were eliminated. The sections and questions added to the questionnaire are shown in Table 3 below.

Table 3. Sections and Questions Added to the Instrument

\begin{tabular}{|c|l|}
\hline \multicolumn{1}{|c|}{ Sections } & \multicolumn{1}{c|}{ Items Added } \\
\hline \multirow{2}{*}{ Navigation } & $\begin{array}{l}\text { All course resources are easily accessible through a minimum number of } \\
\text { clicks. }\end{array}$ \\
\hline \multirow{4}{*}{ Course Assessments } & $\begin{array}{l}\text { Course assessments (i.e. projects, tests) and grading resources for each } \\
\text { assessment (i.e. rubrics, study guides) are available and easy to find. }\end{array}$ \\
\cline { 2 - 3 } & Graded course assignments have clear instructions. \\
\cline { 2 - 3 } & $\begin{array}{l}\text { The resources needed to complete graded course assignments are included (or } \\
\text { linked) on the same page where the instructions are. }\end{array}$ \\
\hline \multirow{5}{*}{ Instructor Presence } & Responses and feedback are received in a reasonable period of time. \\
\cline { 2 - 3 } & $\begin{array}{l}\text { Instructor's contact information (email, phone number) is easy to find and } \\
\text { available in different parts of the course. }\end{array}$ \\
\cline { 2 - 3 } & $\begin{array}{l}\text { Students are continuously encouraged to contact the instructor if they have a } \\
\text { question. }\end{array}$ \\
\hline
\end{tabular}

Phase 3: Experts' Review and Final Questionnaire

In the third phase, three additional experts reviewed the questionnaire that resulted as a product of Phase 2 . These experts were selected using purposive sampling, because they are professional and academic experts in e-learning, having more than 20 years combined experience teaching, designing, and evaluating fully online higher education courses. They were asked to evaluate if each item was: appropriate to measure usability in online courses, easy to 
understand, relevant to the e-learning field, as well as to provide an overall evaluation of the questionnaire. All the experts provided feedback and agreed that some questions were redundant and needed to be deleted. Some of their comments are presented in Table 4. Their comments and suggestions were also analyzed by the researcher and incorporated into the questionnaire, thus obtaining the version that was used in this study.

Table 4. Sample of Phase 3 Experts' Comments and Suggestions

\begin{tabular}{|c|c|}
\hline Item Reviewed & Experts' Comments \\
\hline $\begin{array}{l}\text { The course provides } \\
\text { opportunities for self- } \\
\text { assessments (post-tests and } \\
\text { other assessments) that } \\
\text { advance learners' } \\
\text { achievements according to } \\
\text { the learning objectives. }\end{array}$ & $\begin{array}{l}\text { "The second part of this sentence might not make sense to the learners. } \\
\text { Don't complicate the questions as it will have an adverse impact on the } \\
\text { quality of the responses. The second half is very meaningful to the person } \\
\text { interpreting the results of the survey." }\end{array}$ \\
\hline $\begin{array}{l}\text { Media highlight concepts } \\
\text { rather than distract or } \\
\text { merely entertain learners. }\end{array}$ & $\begin{array}{l}\text { "In terms of surveys this is a biased question. You might remove the bias } \\
\text { by rewording "Throughout the course the media (illustrations, graphics, } \\
\text { and video) aid in the understanding of concepts." }\end{array}$ \\
\hline $\begin{array}{l}\text { The course has interactive } \\
\text { learning tasks to engage } \\
\text { learners. }\end{array}$ & $\begin{array}{l}\text { "Seems like this one has already been asked a couple of times. The survey } \\
\text { is very long and anything you can do to shorten it would be helpful. As } \\
\text { long as you can still get all of the data you desire." }\end{array}$ \\
\hline $\begin{array}{l}\text { Content is organized in an } \\
\text { appropriate sequence and } \\
\text { in small parts for flexible } \\
\text { learning. }\end{array}$ & $\begin{array}{l}\text { "This concerns me for a couple of reasons. First, it has two criteria: } \\
\text { sequence and small parts. What are you trying to measure with this } \\
\text { question? If the leaner feels that the content is not in a proper sequence } \\
\text { OR is not in small parts, then the survey implies that the content is not } \\
\text { organized." }\end{array}$ \\
\hline & Overall Comments \\
\hline \multicolumn{2}{|c|}{$\begin{array}{l}\text { "This is a very long survey and the learners might have survey fatigue near the end of the survey. If you } \\
\text { keep the survey this long, ask the important questions early as they will tend to have more validity in the } \\
\text { quality of the learners' responses. Review the survey and find any way to shorten it. Professionals might } \\
\text { answer a long survey with highly technical questions. Students will not." }\end{array}$} \\
\hline \multicolumn{2}{|c|}{$\begin{array}{l}\text { "In general, it wasn't clear at times if the learner taking the survey was rating their own view of various } \\
\text { elements, or how they thought those elements looked from a general review of the course (not personal } \\
\text { feelings). Using "learners" (plural) seemed to be asking for more general feedback for the whole of the } \\
\text { course instead of personal feedback and opinions. Either direction would be interesting research, or } \\
\text { maybe you want both in survey. I would recommend, when sending the survey out, to directly refer to } \\
\text { the learner when you want them to give you their personal feelings/feedback: "The course allows you to } \\
\text { leave whenever desired...". Or, if you want them to give a more broader, less personal account of how } \\
\text { well the course was designed for all learners, to make it more specific: "The course design allowed } \\
\text { learners to leave whenever desired..."'" }\end{array}$} \\
\hline
\end{tabular}

\section{Testing the Final Questionnaire}

The final version contains 32 questions divided into the following 9 categories: (1) content, (2) learning and support, (3) visual design, (4) navigation, (5) accessibility, (6) interactivity, (7) self-assessment and learnability, (8) course assessments, and (9) instructor presence. The final version that resulted from Phase 3 was tested with real participants to determine its validity and reliability. Participants were students enrolled in one or more fully online courses from January to May 2016 in a South Texas university. A convenience sample was drawn from the students who responded, becoming part of the final sample. Although a convenience sample is not considered a rigorous sample technique (Marshall, 1996), it was an appropriate sampling method because, since participation was anonymous and voluntary, from the target population, only participants willing to be part of the research study were considered part of the final sample. 
The questionnaire was administered at the beginning of the semester. The items in the questionnaire were answered using a 7-point Likert scale, ranging from: 1-Strongly Disagree, 2-Disagree, 3-Somewhat Disagree, 4-Neither Agree or Disagree, 5-Somewhat Agree, 6-Agree, and 7-Strongly Agree. The answers also included a "Not Applicable" option, for those questions that were not applicable for a participant. A total of 520 responses were collected. An Exploratory Factor Analysis (EFA) was then performed.

\section{RESULTS}

From the Exploratory Factor Analysis performed, a total of four factors were extracted. The factor loadings of each of the 32 items were analyzed. Based on the results, 27 questions were considered appropriate to be included in the questionnaire. The factor loadings of the 5 remaining items did not clearly load into any of the four factors. Therefore, these 5 items were removed from the questionnaire. From the removed questions, 2 were from the course assessment criteria, 2 were from the navigation criteria, and 1 was from the learning and support criteria. The following table (Table 5) exhibits the questions that were not suitable to be included in the new questionnaire.

Table 5. Removed Questions

\begin{tabular}{|l|c|}
\hline \multicolumn{1}{|c|}{ Removed Question } & Criteria Related \\
\hline $\begin{array}{l}\text { There are opportunities for me to learn through interaction } \\
\text { with others (discussion or other collaborative activities). }\end{array}$ & Learning and Support \\
\hline $\begin{array}{l}\text { The course design allows me to stop and leave whenever I } \\
\text { want, and easily return to the point where I was. }\end{array}$ & Navigation \\
\hline It is clear what I should do if I get stuck or have questions. & Navigation \\
\hline $\begin{array}{l}\text { Course assessments (projects, tests, etc.) and grading } \\
\text { resources for each assessment (rubrics, study guides, etc.) are } \\
\text { available and easy to find. }\end{array}$ & Course Assessments \\
\hline $\begin{array}{l}\text { The resources needed to complete graded course assignments } \\
\text { are included (or linked) on the same page as the instructions. }\end{array}$ & Course Assessments \\
\hline
\end{tabular}

Based on the EFA results for the new questionnaire, Factor 1 was formed by 9 questions related to content, selfassessment and learnability, learning and support, and course assessment criteria. Factor 2 was formed by 6 questions related to interactivity, self-assessment and learnability, and learning and support criteria. Factor 3 was formed by 3 questions related to instructor presence criteria. Finally, Factor 4 was composed by 9 questions related to navigation, visual design, self-assessment and learnability, and accessibility criteria. Names were given to the four factors based on the items they contained. The factors were named as follows: Factor 1 - Content, Factor $2-$ Interactivity, Factor 3 - Instructor Presence, and Factor 4 - Course Design. These factors became the new criteria for the redesigned questionnaire. Table 6 presents a summary of the items and the criteria to which they were related before and after the EFA, the number of questions, and the names given to the new factors. For this study, the final version of the questionnaire is composed of 27 items to measure usability in online higher education courses. 
Table 6. Factors Extracted for the Redesigned Questionnaire

\begin{tabular}{|c|c|c|}
\hline $\begin{array}{c}\text { Criteria } \\
\text { Originally } \\
\text { Related }\end{array}$ & Item Name & $\begin{array}{c}\text { Number of } \\
\text { items per } \\
\text { Criteria }\end{array}$ \\
\hline \multirow{6}{*}{ Content } & Q01 & \multirow{6}{*}{6} \\
\hline & $\mathrm{Q} 02$ & \\
\hline & $\mathrm{Q} 03$ & \\
\hline & Q04 & \\
\hline & Q05 & \\
\hline & Q06 & \\
\hline \multirow{3}{*}{$\begin{array}{l}\text { Learning } \\
\text { and Support }\end{array}$} & Q07 & \multirow{3}{*}{3} \\
\hline & Q08 & \\
\hline & Q09 & \\
\hline
\end{tabular}

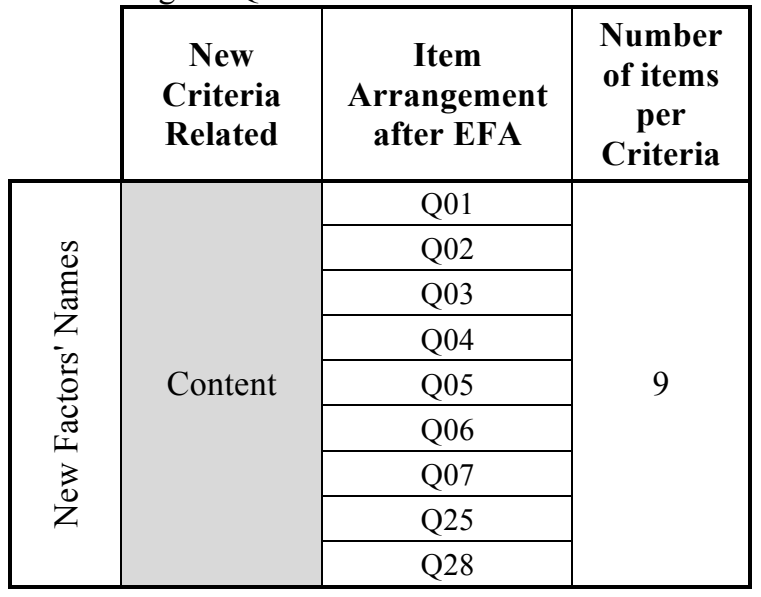

\begin{tabular}{|c|c|c|}
\hline \multirow{3}{*}{$\begin{array}{l}\text { Visual } \\
\text { Design }\end{array}$} & Q10 & \multirow{3}{*}{3} \\
\hline & Q11 & \\
\hline & Q12 & \\
\hline \multirow{4}{*}{ Navigation } & Q13 & \multirow{4}{*}{4} \\
\hline & Q14 & \\
\hline & Q15 & \\
\hline & Q16 & \\
\hline \multirow{2}{*}{ Accessibility } & Q17 & \multirow{2}{*}{2} \\
\hline & Q18 & \\
\hline \multirow{4}{*}{ Interactivity } & Q19 & \multirow{4}{*}{4} \\
\hline & Q20 & \\
\hline & Q21 & \\
\hline & Q22 & \\
\hline \multirow{4}{*}{$\begin{array}{c}\text { Self- } \\
\text { Assessment } \\
\text { and } \\
\text { Learnability }\end{array}$} & Q23 & \multirow{4}{*}{4} \\
\hline & Q24 & \\
\hline & Q25 & \\
\hline & Q26 & \\
\hline \multirow{3}{*}{$\begin{array}{c}\text { Course } \\
\text { Assessments }\end{array}$} & Q27 & \multirow{3}{*}{3} \\
\hline & Q28 & \\
\hline & Q29 & \\
\hline \multirow{3}{*}{$\begin{array}{l}\text { Instructor } \\
\text { Presence }\end{array}$} & Q30 & \multirow{3}{*}{3} \\
\hline & Q31 & \\
\hline & Q32 & \\
\hline & Total & 32 \\
\hline
\end{tabular}

\begin{tabular}{|c|c|c|c|}
\hline \multirow{18}{*}{ 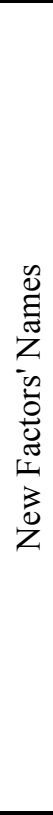 } & \multirow{6}{*}{ Interactivity } & Q08 & \multirow{6}{*}{6} \\
\hline & & Q19 & \\
\hline & & Q20 & \\
\hline & & Q21 & \\
\hline & & Q22 & \\
\hline & & Q26 & \\
\hline & \multirow{3}{*}{$\begin{array}{l}\text { Instructor } \\
\text { Presence }\end{array}$} & Q30 & \multirow{3}{*}{3} \\
\hline & & Q31 & \\
\hline & & Q32 & \\
\hline & \multirow{9}{*}{$\begin{array}{l}\text { Course } \\
\text { Design }\end{array}$} & Q10 & \multirow{9}{*}{9} \\
\hline & & Q11 & \\
\hline & & Q12 & \\
\hline & & Q13 & \\
\hline & & Q16 & \\
\hline & & Q17 & \\
\hline & & Q18 & \\
\hline & & Q23 & \\
\hline & & Q24 & \\
\hline & & Total & 27 \\
\hline
\end{tabular}

This questionnaire was validated using content validity, which looks at the appropriateness of content. Content validity is measured giving each question to a panel of subject matter experts, who "give their opinion about whether the question is essential, useful or irrelevant to measuring the construct under study" (Shuttleworth, 2009, para. 7). Since each item in the adapted questionnaire was revised based on subject matter experts' input, the final version was considered valid. Overall, the internal consistency reliability of each factor on the questionnaire is higher than the recommended value of 0.80 . Therefore, at this point the questionnaire is considered valid and reliable, and can be used to measure usability in online higher education courses. 


\section{CONCLUSIONS}

According to Melis, Weber, and Andrès (2003), "the usability of an e-learning system is a key feature for its success (para. 1)." Therefore, the measurement of the usability perception of an online course is important to determine if a course is considered successful. Students taking online courses should not struggle with a course because of its usability, which could affect their grades and/or learning, or even cause them to drop the course. If a course is welldesigned, students do not get confused and their energy and efforts are used in their own learning process. Based on the above, measuring online courses usability allows faculty and course designers to find courses' weaknesses in order to improve them, offering a good course-experience to students.

The purpose of this study was to redesign an instrument, originally created to measure usability in corporate settings, to be used to measure usability in fully online higher education courses. The redesign process, which was conducted in 3 phases, was presented in this article. Some items from the original questionnaire developed by Zaharias (2009) for corporate settings, were adapted by the researcher to educational settings in Phase 1. In Phase 2 and Phase 3, subject matter experts reviewed the questionnaire and their suggestions on each item were analyzed and incorporated. The final version of the questionnaire was pilot tested and the results were analyzed. As a result of the analysis, the redesigned questionnaire is considered valid and reliable, and it can be used to measure usability in online higher education courses.

The redesigned questionnaire collects students' perceptions about an online course's usability. Based on the questionnaire's results, usability weaknesses can be improved in order to offer a better course experience to the students. Although the questionnaire was designed to collect students' usability perceptions taking an already designed online higher education course, this questionnaire can also be used at the design stage of online courses. During the course development process, course designers can consider each item in the questionnaire and apply them to the online courses being designed. Since online higher education courses are delivered in many different ways and use different Learning Management Systems (LMS), the items included in the redesigned questionnaire were designed to apply to courses with diverse characteristics.

Online course designs, tools, and even online students' characteristics are constantly changing as technology evolves. Therefore, usability can be constantly measured in order to detect course's weaknesses and improve them as the courses are requiring it. As future research on this study, the redesigned questionnaire can be applied in different higher education institutions, with students with different course levels and characteristics, and different course designs in order to find improvement areas and the differences between one course's characteristics and another's. Also, the outcomes of the application of the questionnaire at diverse points of the course (including the designing stage) could be further studied.

\section{REFERENCES}

Abran, A., Khelifi, A., Suryn, W., \& Seffah, A. (2003). Usability meanings and interpretations in ISO standards. Software Quality Journal, 11, 325-338.

Arend, B. (2007). Course assessment practices and student learning strategies in online courses. Online Learning Journal, 11(4), 3-17.

Aziz, M. A., Isa, W. A., \& Nordin, N. (2010) Assessing the accessibility and usability of Malaysia higher education website. 2010 International Conference on User Science Engineering (i-USEr), 203 - 208.

Baker, C. (2010). The impact of instructor immediacy and presence for online student affective learning, cognition, and motivation. The Journal of Educators Online, 7(1), 1-30.

Ballard, J. K. (2010). Web site usability: A case study of student perceptions of educational websites. (Doctoral dissertation). Retrieved from http://conservancy.umn.edu/handle/11299/91797 
Bevan, N., Kirakowski, J., \& Maissel, J. (1991). What is usability? $4^{\text {th }}$ International Conference on Human Computer Interaction. Stuttgart, September 1991. Elsevier.

David, A., \& Glore, P. (2010). The impact of design and aesthetics on usability, credibility, and learning in an online environment. Online Journal of Distance Learning Administration, 13(4), 43-50. Retrieved from http://www.westga.edu/ distance/ojdla/winter134/david_glore134.html

Davids, M. R., Chikte, U. M., \& Halperin, M. L. (2014). Effect of improving the usability of an e-learning resource: A randomized trial. Advances in Physiology Education, 38, 155-160. doi: 10.1152/advan.00119.2013

Dringus, L. P., \& Cohen, M. S. (2005). An adaptable usability heuristic checklist for online courses. 35th ASEE/IEEE Frontiers in Education Conference, T2H-6 - T2H-11.

Explorable.com (Sep 16, 2009). Convenience Sampling. Retrieved Apr 13, 2016 from Explorable.com: https://explorable.com/convenience-sampling

Feldstein, M., \& Neal, L. (2006, August). Designing usable, self-paced e-learning courses: A practical guide. Retrieved from: http://elearnmag.acm.org/featured.cfm?aid=1165344

Fisher, E. A., \& Wright, V. H. (2010). Improving online course design through usability testing. MERLOT Journal of Online Learning and Teaching. 6(1). 228-245.

Gaytan, J. \& McEwen, B. (2007). Effective online instructional and assessment strategies. The American Journal of Distance Education, 21(3), 117-132.

Granić, A., \& Ćukušić, M. (2011). Usability testing and expert inspections complemented by educational evaluation: A case study for an e-Learning platform. Educational Technology \& Society, 14(2), 107-123.

Heidig, S., Müller, J., \& Reichelt, M. (2015). Emotional design in multimedia learning: Differentiation on relevant design features and their effects on emotions and learning. Computers in Human Behavior. 44, 81-95.

Hu, Y. (2008). Motivation, usability and their interrelationships in a self-paced online learning environment (Doctoral dissertation). Retrieved from http://scholar.lib.vt.edu/theses/available/etd-09022008091550/unrestricted/Hu_Dissertation_etd.pdf

Jokela, T., Iivari, N., Matero, J., \& Karukka, M. (2003). The standard of user-centered design and the standard definition of usability: Analyzing ISO 13407 against ISO 9241-11. In Proceedings of the Latin American Conference on Human-Computer Interaction (pp. 53-60). ACM.

Jones, I. M. (2011). Can you see me now? Defining teaching presence in the online classroom through building a learning community. Journal of Legal Studies Education. 28(1), 67-116.

Khan, M. A., Israr, N., \& Hassan, S. (2010). Usability evaluation of web office applications in collaborative writing. 2010 International Conference on Intelligent Systems, Modeling and Simulation, 146-151. doi: 10.1109/ISMS.2010.37

Malamed, C. (2015, April 28) Why aesthetics matter to learning. Association for Talent Development. Retrieved from: https://www.td.org/Publications/Blogs/Learning-Technologies-Blog/2015/04/Why-AestheticsMatter-to-Learning

Marshall, M. N. (1996). Sampling for qualitative research. Oxford University Press, 13(6).

Mazumder, F. K., \& Das, U. K. (2014). Usability guidelines for usable user interface. IJRET: International Journal of Research in Engineering and Technology. 3(9), 79-82. eISSN: 2319-1163 
Melis, E., Weber, M., \& Andrès, E. (2003, November). Lessons for (pedagogic) usability of eLearning systems. In Proceedings of World Conference on E-Learning in Corporate, Government, Healthcare, and Higher Education (Chesapeake, VA, USA,). Ed. by A. Rossett. AACE.

Nasreen, N., \& Alawi, G. A. (2011). Impact of digital library and internet technology on learner's usability and satisfaction. 2011 IEEE International Conference on Technology for Education, 128 - 135. doi: 10.1109/T4E.2011.28

Nielsen, J. (1995a). 10 Usability heuristics for user interface design. Nielsen Norman Group. Retrieved from: http:/www.nngroup.com/articles/ten-usability-heuristics/

Nielsen, J. (1995b). How to conduct a heuristic evaluation. Nielsen Norman Group. Retrieved from: http:/www.nngroup.com/articles/how-to-conduct-a-heuristic-evaluation/

Nokelainen, P. (2006). An empirical assessment of pedagogical usability criteria for digital learning material with elementary school students. Educational Technology \& Society, 9(2), pp 178-197.

Nyang'or, J. O., De Villiers, M.R. \& Ssemugabi, S. (2013). A framework for usability evaluation of an offline elearning tutorial and its application in usability testing. In Jan Herrington et al. (Eds.), Proceedings of World Conference on Educational Multimedia, Hypermedia and Telecommunications 2013 (pp. $1097-$ 1105). Chesapeake, VA: AACE.

Nyang'or, J. O., Ssemugabi, S. \& De Villiers, R.M. (2013). Optimising the effectiveness of questionnaire surveys for usability evaluation of offline e-learning tutorials. In T. Bastiaens \& G. Marks (Eds.), Proceedings of World Conference on E-Learning in Corporate, Government, Healthcare, and Higher Education 2013 (pp. 387-394). Chesapeake, VA: AACE.

Orehovacki, T., \& Hrustek, N. Z. (2013). Towards a framework for usability evaluation of educational artifacts created with web 2.0 applications: A pilot study. MIPRO 2013, 565-570.

Plass, J., Heidig, S., Hayward, E., Homer, B., \& Um, E. (2013). Emotional design in multimedia learning: Effects of shapeand color on affect and learning. Learning and Instruction. doi: 10.1016/j.learninstruc.2013.02.006

Poe, M. \& Stassen, M. L. A. (Eds.) (n. d.) Assessing student learning. In Teaching and learning online: Communication, community, and assessment. (35-39) Retrieved from http://www.umass.edu/oapa/oapa/ publications/online_handbooks/Teaching_and_Learning_Online_Handbook.pdf

Rocherster Institute of Technology, (n. d.). Assessing student learning outcomes in an online environment. Retrieved from https://www.rit.edu/academicaffairs/outcomes/online-student-learning-outcomes-assessment

Shackel, B. (2009). Usability - context, framework, definition, design and evaluation. Interacting with Computers 21, 339-346.

Shea, P., Li, C. S., \& Pickett, A. (2006). A study of teaching presence and student sense of learning community in fully online and web-enhanced college courses. Internet and Higher Education, 9, 175-190.

Shea, P., Li, C. S., Swan, K., \& Pickett, A. (2005). Developing learning community in online asynchronous college courses: The role of teaching presence. Journal of Asynchronous Learning Networks, 9(4), 59-82.

Shuttleworth, M. (Jul 6, 2009). Content Validity. Retrieved Apr 14, 2016 from Explorable.com: https://explorable.com/content-validity 


\section{Issues in Information Systems \\ Volume 17, Issue III, pp. 77-88, 2016}

Silius, K., Tervakari, A., Pohjolainen, S. (2003). A multidisciplinary tool for the evaluation of usability , pedagogical usability, accessibility and informational quality of web-based courses. The Eleventh International PEG Conference: Powerful ICT for Teaching and Learning.

Shneiderman, B., \& Plaisant, C. (2010). Designing the User Interface: Strategies for Effective Human-Computer Interaction: Fifth Edition, Addison-Wesley Publ. Co., Reading, MA.

Stergioulas, L., Abbasi, M., Xydopoulos, G., Fakhimi, M., Margineanu, R., Rifon, L. A., \& Iglesias, M. F. (2014). Evaluating e-learning platforms for schools: Use and usability, user acceptance, and impact on learning. 2014 IEEE $14^{\text {th }}$ International Conference on Advanced Learning Technologies, 19-21. doi: 10.1109/ICALT.2014.16

Swan, K., Shen, J., \& Hiltz, S. R. (2006). Assessment and collaboration in online learning. Journal of Asynchronous Learning Networks, 10(1), 45-62.

Tu, C., \& McIsaac, M. (2002). The relationship of social presence and interaction in online classes. The American Journal of Distance Education, 16(3), 131-150.

Zaharias, P. (2009). Developing a usability evaluation method for e-learning applications: From functional usability to motivation to learn. International Journal of Human-Computer Interaction, 25(1), 75-98.

Zaharias, P., \& Koutsabasis, P. (2012). Heuristic evaluation of e-learning courses: A comparative analysis of two elearning heuristic sets. Campus Wide Information Systems, 29(1), 45-60. doi: 10.1108/10650741211192046 